\title{
Efektivitas Pengurusan Hak Tanggungan Elektronik di Kantor Pertanahan Kabupaten Buleleng
}

\section{Ni Ny. Mariadi1*, I Komang Kawi Arta²}

1,2 Fakultas Hukum, Universitas Panji Sakti,Singaraja, Indonesia

\section{ART I CLE IN F O}

\section{Article history:}

Received August 12, 2021

Revised August 13, 2021

Accepted October 10, 2021

Available online October 25, 2021

Kata Kunci:

Efektivitas Hukum, Hak Tanggungan Elektronik

Keywords:

Legal Effectiveness, Electronic Mortgage

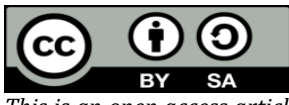

This is an open access article under the $\mathrm{CC}$ BY-SA license.

Copyright (C) 2021 by Author. Published by Universitas Pendidikan Ganesha.

\begin{abstract}
A B S T R A K
Pengguna baik pihak PPAT maupun pihak kreditor pengguna HT-el yang salah memasukkan data, sehingga dari BPN (Badan Pertanahan Nasional) terhambat untuk menyelesaikan secara cepat pengurusan HT-el. HT-el memang dapat mempercepat prosedur pengurusan hak tanggungan, namun masih ada suatu kendala lain seperti sistem atau jaringan yang eror pada saat proses pengurusan HT-el. Tujuan penelitian ini yaitu menganalisis efektivitas Pengurusan Hak Tanggungan Elektronik di Kantor Pertanahan Kabupaten Buleleng dan kendala serta upaya Pengurusan Hak Tanggungan Elektronik di Kantor Pertanahan Kabupaten Buleleng. Jenis penelitian ini yaitu penelitian hukum empiris pendekatan melalui yuridis sosiologis. Sumber data penelitian dari wawancara yang dilakukan di Kantor Pertanahan Kabupaten Buleleng dan ditambah melalui studi kepustakaan untuk dapat memperoleh data sekundernya. Sampel penelitian menggunakan sampel purposive sampling. Hasil penelitian ini menunjukkan bahwa Efektivitas Pengurusan Hak Tanggungan Elektronik sudah efektif, namun apabila dikaji dengan teori efektivitas hukum. Pada bagian budaya hukum mengenai HT-el yang masih terdapat beberapa kendala yang harus perlu penyeseuaian budaya hukum yang semula pengurusan Hak Tanggungan secara manual dengan perkembangan teknologi sekarang menjadi pengurusan Hak Tanggungan secara elektronik. Kendala yang dihadapi dari sisi server dan jaringan, serta teknis penggunaan dari HT-el tersebut. Diperlukan suatu server yang memadai dan terus dilakukan sosialisasi dan pembekalan terhadap HT-el tersebut kepada pengguna Ht-el, supaya pengguna dapat cepat beradaptasi dengan budaya hukum pengurusan HT-el saat ini.
\end{abstract}

\begin{abstract}
A B S TRACT
Users, both PPAT and creditors, HT-el users who enter the data incorrectly, so it is from BPN (National Land Agency) to quickly complete the processing of HT-el. HT-el can predict the procedure for managing mortgage rights. Other obstacles exist, such as system or network errors during the HT-el management process. The purpose of this study is to analyze the effectiveness of Electronic Mortgage Management at the Buleleng Regency Land Office and the obstacles and efforts to manage Electronic Mortgage Rights at the Buleleng Regency Land Office. This type of research is an empirical legal research approach through sociological juridical. Sources of research data from interviews conducted at the Land Office of Buleleng Regency and added through library research to obtain secondary data. The research sample used purposive sampling. This study indicates that the Effectiveness of Electronic Mortgage Management is effective but is reviewed based on the theory of legal effectiveness. In the section on legal culture regarding HT-el, several obstacles must be adjusted to the legal culture, which was initially manual mortgage management with technological developments, now it is electronic mortgage management. Constraints faced from the server and network side and the technical use of the HTel. an adequate server and continuing to carry out socialization and briefing of the HT-el to Ht-el users so that users can quickly adapt to the current legal culture of HT-el management.
\end{abstract}

\section{PENDAHULUAN}

Pemberian kredit dapat dilakukan melalui perjanjian kredit antara pemberi dengan penerima kredit sehingga terjadi hubungan hukum (Sinha \& Verma, 2020; Tadesse \& Zewdie, 2019). Saat dilapangan sering kali ditemukan perjanjian kredit yang dibuat oleh kreditur, sedangkan debitur hanya memahami dan mempelajari dengan baik. Perjanjian kredit memiliki fungsi yang sangat penting dalam pemberian, pengelolaan dan penatalaksanaan kredit dalam kesepakatan yang dilakukan antara kreditur dan debitur (Basuki, 2015; Kamaluddin \& Haryati, 2020; Situmorang et al., 2019). Jika debitur menandatangani perjanjian kredit yang dianggap mengikat kedua belah pihak dan berlaku sebagai undang-undang bagi keduanya. Kredit merupakaan penyediaan uang ataupun tagihan berdasarkan kesepakatan pijam-meminjam antar bara bank (Ginting \& Permana, 2018; Saragih et al., 2018). Peminjam 
wajib untuk melunasi utang setelah jangka waktu yang telah ditentukan sebelumnya oleh pihak bank dengan pemberian bunga (Munawaroh, 2011; Pratama, 2015).

Sejak aturan mengenai HT-el dikeluarkan, maka saat itu lingkungan di bawah kementerian ATR/BPN yaitu kantor pertanahan di seluruh Indonesia melaksanakan aturan mengenai HT-el tersebut. Salah satu Kantor Pertanahan yang melaksanakan adalah Kantor Pertanahan di Kabupaten Buleleng-Bali. Tujuan dari dilaksanakan HT-el adalah untuk memudahkan dan mengefesienkan waktu pengguna dalam melakukan pengurusan HT-el. Tetapi dalam pratiknya ada beberapa kendala yang sering dihadapi dalam pengurusan HT-el tersebut. Berdasarkan hasil observasi di kantor pertanahan Kabupaten Buleleng, bahwa informasi awal, ada kendala yang dihadapi, yaitu Pengguna baik pihak PPAT maupun pihak kreditor pengguna HT-el yang salah memasukkan data, sehingga dari BPN (Badan Pertanahan Nasional) kabupaten Buleleng terhambat untuk menyelesaikan secara cepat pengurusan HT-el. Pengguna HT-el yang salah menginput data terkadang dari pihak yang sudah berumur, sehingga kurang paham terhadap teknologi. Hal ini menjadi suatu permasalahan, satu sisi sudah ada aturan yang mengatur mengenai HT-el, namun disisi lain masih ada masalah terhadap data yang di inputnya sehingga pihak pengguna datang langsung ke kantor pertanahan Kabupaten Buleleng. HT-el memang dapat mempercepat prosedur pengurusan hak tanggungan, namun masih ada suatu kendala lain seperti sistem atau jaringan yang eror pada saat proses pengurusan HT-el. Apalagi Hak Tanggungan secara elektronik (HT-el) dapat dikatakan baru dilaksanakan, maka perlu penyesuaian dari pengguna maupun pelaksana dalam hal ini kantor pertanahan setempat terhadap hak tanggunan elektronik tersebut. Adanya suatu kendala akan mempengaruhi juga kinerja PPAT, karena dalam waktu selambat-lambatnya tujuh hari setelah penandatangan akta pemberian hak tanggungan, PPAT wajib mendaftarkan akta tersebut kepada kantor pertanahan Kabupaten/Kota Setempat.

Berkenaan dengan praktik pemberian kredit dengan jaminan tanah, diperlukan lembaga hak jaminan yang mampu memberikan kepastian hukum bagi pihak-pihak yang berkepentingan. UndangUndang Nomor 4 Tahun 1996 tentang Hak Tanggungan Atas Tanah Beserta Benda-benda Yang Berkaitan Dengan Tanah tersebut atau disingkat "UUHT" (Basit, 2016; Catur, 2014). Perkembangan Hak Tanggungan di Indonesia berjalan bersamaan dengan teknologi yang ada di Indonesia yang begitu canggih (Jayanti \& Darmawan, 2018; Nugroho, 2018; Pribadi, 2017). Terbukti Pemerintah menyediakan layanan Pendaftaran Hak Tanggungan yang terintegrasi secara elektronik berdasarkan Peraturan Kepala Badan Pertanahan Nasional Nomor 9 Tahun 2019 dan Permen ATR/BPN Nomor 5 Tahun 2020 tentang Pelayanan Hak Tanggungan secara Elektronik dengan "HT-el” (Guntoro et al., 2020; Nurwulan, 2021).

Tanggungan diartikan sebagai barang yang akan dijadikan jaminan, sedangkan jaminan itu sendiri memiliki arti tanggungan atas pinjaman yang diterima (Adi Widjaja \& Winarno, 2018; Fahmi et al., 2020). Berdasarkan Permen ATR/BPN yang menjadi pengguna layanan sistem Hak Tanggungan Elektronik adalah pertama PPAT (Pejabat Pembuat Akta Tanah) sebagai pejabat yang membuat APHT (Akta Pemberian Hak Tanggungan) (Badriyah, 2016; Surbakti et al., 2018). Pihak lain yang menggunakan HT-el adalah Kreditor. Keditor biasanya merupakan institusi keuangan Perbankan dan bisa juga Perseorangan, kreditor dalam pelayanan HT -el adalah pihak yang berpiutang dalam satu hubungan utang piutang tertentu (Setiawan et al., 2018; Yulianingsih \& Noviana, 2012). Sama halnya dengan PPAT maka Kreditor yang dapat menggunakan system HT-el adalah kreditor yang terdaftar di aplikasi Mitra Jasa Keuangan pada mitra.atrbpn.go.id. Berdasarkan uraian di atas, diperlukan penelitian lebih dalam untuk mengkaji permasalahan tersebut. Tujuan penelitian ini yaitu menganalisis efektivitas Pengurusan Hak Tanggungan Elektronik di Kantor Pertanahan Kabupaten Buleleng dan kendala serta upaya Pengurusan Hak Tanggungan Elektronik di Kantor Pertanahan Kabupaten Buleleng.

\section{METODE}

Jenis penelitian yang digunakan adalah penelitian hukum empiris. Penelitian hukum empiris adalah penelitian dengan melihat sesuatu kenyataan di dalam masyarakat (Hurlock, 2009). Penelitian ini difokuskan pada menguji efektivitas hukum yang berlaku di kantor pertanahan kabupaten buleleng terkait dengan Hak Tanggungan Elektronik. Data penelitian yang digunakan adalah Data Primer, yaitu data yang diperoleh melalui hasil wawancara kepada para responden di lokasi penelitian. Data primer dalam penelitian ini diperoleh dari hasil wawancara yang dilakukan kepada di Kantor Pertanahan Kabupaten Buleleng yang khusus bagian penetapan hak pendaftaran. Data Sekunder, yaitu data-data yang diperoleh dari beberapa literatur yang berkaitan dengan obyek penelitian ini. Data tersebut diperoleh dari Perpustakaan Fakultas Hukum Universitas Panji Sakti dan Perpustakaan Umum. Teknik analisis data yang akan digunakan dalam penelitian ini adalah analisis deskritif kualitatif yaitu peneliti mendiskripsikan data-data yang di peroleh dilapangan (wawancara, dokumentasi, observasi) dari data tersebut kemudian dilakukan analisa untuk permasalahan yang terdapat dalam rumusan masalah. 


\section{HASIL DAN PEMBAHASAN}

Hasil

Hak tanggungan ialah hak jaminan pada tanah. Hak tanggungan dengan perjanjian pembebanan jaminan yang muncul karena perjanjian kredit antara pihak debitur dengan kreditur baik dibuat dibawah tangan maupun dengan akta notaris. Perjanjian kredit dibawah tangan berarti perjanjian tersebut dibuat para pihak yaitu kreditur dan debitur tanpa ada pejabat berwenang, sedangkan perjanjian kredit dengan akta notaris berarti perjanjian dibuat para pihak dihadapan notaris. Objek dari hak tanggungan ialah tanah. Pendapat Budi Harsono ada 4 syarat hak atas tanah agar bisa menjadi jaminan: dapat dinilai dengan uang, hak terdaftar pada daftar umum karena harus memenuhi syarat publisitas, sifat dapat dipindah tangankan, jika debitur wanprestasi benda jaminan akan dijual dimuka umum, dan perlu penunjukan dengan Undang-Undang.

Jika dilihat dari Pasal 4 ayat (1) dan ayat (2) Undang-Undang Hak Tanggungan diketahui yang dibebani hak tanggungan ialah hak milik, hak guna usaha, hak guna bangunan, dan hak pakai. Untuk membebankan hak tanggungan, maka perlu dibuatkan APHT oleh PPAT yang berisi pemberian hak tanggungan pada kreditur tertentu. Guna mendapatkan kekuatan hukum, hak tanggungan dituangkan dalam APHT tersebut haruslah didaftarkan. Sistem HT-el dikelola oleh Kantor Pertanahan sesuai Pasal 4 ayat (1) dan adapun jenis pelayanan dalam sistem HT-el pada Pasal 6 menentukan "jenis layanan hak tanggungan yang dapat diajukan melalui sistem HT-el, meliputi: a. pendaftaran hak tanggungan; $b$. peralihan hak tanggungan; c. perubahan nama kreditur; d. penghapusan hak tanggungan (Wiguna, 2020).

Hak tanggungan sebagai hak penguasaan atas tanah yang berisikan kewenangan bagi kreditor untuk berbuat sesuatu mengenai tanah yang dijadikan agunan, tetapi bukan untuk dikuasai secara fisik dan digunakan, melainkan untuk menjualnya jika debitur cedera janji (wanprestasi) dan mengambil hasilnya, baik seluruh atau sebagian sebagai pembayaran lunas hutang debitur kepadanya. Pada Pasal 1 angka 7 Peraturan Menteri ATR/BPN RI Nomor 5 tahun 2020 Tentang Pelayanan Hak Tanggungan Terintegritas Secara Elektronik yang selanjutnya di sebut Ht-el adalah serangkaian proses pelayanan hak tanggungan dalam rangka pemeliharaan data pendaftaran tanah diselenggarakan melalui sistem elektronik yang terintegritas.

Sejak aturan hukum Hak Tanggungan elektronik di tetapkan, pihak kantor Pertanahan Kabupaten Buleleng masih mempersiapkan baik dari bagian di kantor pertanahan maupun dari Pejabat Pembuat Akta Tanah (PPAT) dan Jasa Keuangan seperti perbankkan. Adanya sosialisasi pengenalan terlebih dahulu yang di lakukan oleh pihak Kanwil ATR/BPN di buleleng yang menyasar pihak PPAT. Pihak kantor pertanahan juga melakukan sosialiasi terkait dengan HT-el terhadap jasa keuangan, sehingga berlakunya penerapan HT-el di Kantor Pertanahan di Kabupaten Buleleng sejak bulan januari tahun 2020. Disamping adanya sosialisasi di tambah juga pelaksanaan praktik dari cara menggunakan HT-el, supaya pengguna tersebut lebih memahami dari HT-el.

Pada hierarki hak-hak penguasaan atas tanah dalam Hukum Agraria Nasional, antara lain: hak bangsa indonesia atas tanah, hak menguasai dari negara atas tanah, hak ulayat masyarakat hukum adat, hak perseorangan atas tanah, meliputi : hak-hak atas tanah, wakaf tanah hak milik, hak tanggungan dan hak milik atas satuan rumah susun (Arta \& Qurbani, 2021). Hak-hak atas tanah salah satunya seperti hak milik perseorangan atas tanah. Pada tataran instrumen hukum nasional, terhadap hak-hak individual juga telah dijamin dan diatur. Pengaturan terhadap hak-hak individual ini juga tersebar di berbagai peraturan perundang-undangan. Pada Pasal 16 UUPA, bahwa hak-hak atas tanah yang dapat diberikan kepada dan dipunyai oleh orang-orang lain serta badan hukum. Hak tanggungan merupakan hak yang termasuk dalam hak perseorangan. Penyelenggaraan hak tanggungan semula dilakukan dengan cara manual dan setelah perkembangan teknologi yang begitu pesat, maka keluarlah aturan mengenai pelayanan dari hak tanggungan elektronik.

Pasal 51 UUPA ditentukan bahwa Hak Tanggungan dapat dibebankan kepada Hak Milik, Hak Guna Usaha dan Hak Guna Bangunan yang diatur dengan undang-undang. Berdasarkan amanat Pasal 51 UUPA tersebut, maka diundangkan UndangUndang Nomor 4 Tahun 1996 tentang Hak Tanggungan Atas Tanah Beserta Benda-Benda Yang Berkaitan Dengan Tanah (UUHT). Hukum Acarapun mengilhami Pasal 51 UUPA tersebut untuk membentuk rezim hukum khusus tentang HT sebagaimana diamanatkan Pasal 1178 KUHPdt, yaitu adanya kekuatan eksekusi bukan hanya dari putusan pengadilan (Pasl 224 HIR), tetapi juga dapat berasal dari perjanjian (Prayuti et al., 2019). Jenis Layanan dan Objek Hak Tanggungan Pasal 6 (1) Jenis Pelayanan HT-el yang dapat diajukan melalui Sistem HT-el meliputi: pendaftaran Hak Tanggungan, peralihan Hak Tanggungan, perubahan nama Kreditor, penghapusan Hak Tanggungan, perbaikan data.

Mengingat Penyelenggaraan pelayanan dari HT-el terdiri dari perorangan atau Badan Hukum (sebagai Kreditor), PPAT, dan ASN Kementerian Agraria/BPN (sebagai pelaksana). PPAT wajib menggunakan aplikasi yang disediakan Kementerian ATR/BPN dengan menjadi mitra kerja di BPN, mendaftar dan membuat akun secara online melalui portal mitra kerja di browser dengan alamat: 
https://mitra.atrbpn.go.id/datappat/login. Jika tidak melakukan pemutakhiran data maka tidak dapat mengakses dan mendaftarkan layanan pada aplikasi pelayanan pertanahan secara elektronik. Sehingga PPAT tidak dapat menjadi pengguna dalam pelayanan Hak Tanggungan Elektronik tersebut (Nurwulan, 2021).

Namun bagi masyarakat secara umum yang tidak langsung sebagai pengguna dari ht-el ini tidak diadakan sosialisasi, tetapi bagi kreditur perorangan harus tahu dari sistem ht-el tersebut dan cara menggunakan serta mendaftarkan akunnya melalui aplikasi yang disediakan oleh kantor pertanahan. Mekanisme pendaftaran Ht-el dimulai dari pihak bank atau jasa keuangan mengadakan suatu perjanjian kredit dengan debitur, kemudian dituangkan dalam akta PPAT mengenai data-data dari kreditur dan data dari debitur. Pihak PPAT melakukan pengecekan sertipikat pemohon ke Badan Pertanahan Nasional (BPN). Tujuannya untuk sebelum melaksanakan pembuatan akta mengenai pemindahan atau pembebanan hak atas tanah atau hak milik atas satuan rumah susun, PPAT wajib terlebih dahulu melakukan pemeriksaan pada kantor pertanahan mengenai kesesuaian sertipikat hak atas tanah atau hak milik atas satuan rumah susun yang bersangkutan dengan daftar-daftar yang ada di Kantor Pertanahan dengan memperlihatkan sertipikat asli (Pasal 97 Ayat 1 Peraturan Menteri Negara Agraria/ Kepala Badan Pertanahan Nasional Nomor 3 Tahun 1997 tentang Ketentuan Pelaksanaan Peraturan Pemerintah Nomor 24 Tahun 1997 tentang Pendaftaran Tanah).

Menurut Nurudin, dalam jurnal Urgensi Penetapan Limitasi waktu pemeriksaan kesesuaian sertipikat hak atas tanah di kantor pertanahan sebelum pembuatan akta oleh PPAT menyatakan bahwa fungsi pengecekan sertipikat adalah mengetahui di buku tanah, apa tanah tersebut sedang tidak dalam keadaan sengketa atau apa tanah tersebut di bebani dengan suatu hak tanggungan (https://www.kompasiana.com/renabudiarti/ diakses pada senin, 15 November : 2021). Saat ini pengecekan sertipikat juga dilaksanakan secara online.

Setelah adanya suatu pengecekan sertipikat hak atas tanah secara online sebagaimana prosedur diatas yang gunanya melihat tanah tersebut ada masalah atau tidak. Jika tidak ada masalah terhadap sertipikat tersebut, kemudian di pasang hak tanggungan. Prosedurnya pertama dari pihak Bank setelah adanya perjanjian kredit dari pihak kreditur dan debitur yang di buat oleh notaris, kemudian pihak Bank membuat surat order untuk diberitahuan kepada PPAT rekanan untuk melakukan suatu pengecekan sertipikat di BPN. Sesuai prosedur pengecekan sertipikat tersebut diatas, kemudian sudah selesai pengecekan, pihak PPAT meng upload data-data pemohon, seperti ; Kartu Tanda Penduduk (KTP) Pemohon/debitur, Kartu Keluarga (KK) Pemohon/ debitur, perjanjian kredit, Surat Kuasa Membebankan Hak tanggungan (SKMHT), Akta Pembebanan Hak Tanggungan (APHT), Surat Pemberian Pajak Terhutang (SPPT).

Jika terjadi kesalahan data-data yang di upload oleh pihak PPAT selama proses pengurusan HT-el, pihak PPAT di konfirmasi ke oleh pihak BPN atau disebut proses penangguhan. Proses penangguhan tersebut isinya data-data yang salah di informasikan oleh BPN dan pihak PPAT yang kemudian memperbaiki data yang salah tersebut. Setelah diperbaiki kemudian di kirim melalui sistem HT-el tersebut. Kalau tidak ada lagi permasalahan terkait dengan data-data yang di upload PPAT, kemudian pihak PPAT mengkonfirmasi pihak jasa keuangan (Bank). Pihak jasa keuangan (bank) yang kemudian mendaftarkan melalui sistem HT-el dan pihak PPAT hanya membuat akta hak tanggungan dan mengupload data yang sudah diterima dari jasa keuangan (Bank).

Kemudian setelah di upload oleh pihak PPAT akan keluar Surat Pengantar Akta (SPA). Keluarnya Surat Pengantar Akta (SPA) ini yang masuk di sistem PPAT, kemudian di kirimkan SPA tersebut oleh PPAT ke pihak jasa keuangan. Pihak jasa keuangan meng input data-data dari SPA dan pihak jasa keuangan meng input hanya surat permohonan pemasangan hak tanggungan. Pendaftaran dari pihak jasa keuangan (bank) dalam mengupload data-data tidak boleh lebih dari 7 (Tujuh) hari kerja, karena jika lebih dari 7 (Tujuh) hari kerja, maka akta PPAT tersebut dapat dibatalkan. Sesuai dengan ketentuan Pasal 40 Ayat 1 PP 24 Tahun 1997 tentang pendaftaran tanah yang menyatakan bahwa selambat-lambatnya 7 (tujuh) hari kerja sejak tanggal ditandatanganinya akta yang bersangkutan, PPAT wajib menyampaikan akta yang dibuatnya berikut dokumen-dokumen yang bersangkutan kepada kantor pertanahan untuk di daftar.

Setelah di input oleh pihak jasa keuangan akan keluar SPS (Surat Perintah Setor) yang akan dibayar oleh pihak jasa keuangan sesuai nilai Penerimaan Negara Bukan Pajak (PNBP) dengan waktu 3 (tiga) hari. Setelah di bayar, kemudian baru masuk datanya di bagian pelaksana Badan Pertanahan Nasional Kabupaten Buleleng. Kemudian pihak pelaksana (BPN) yang mengkoreksi data-data yang diajukan tersebut.

Pihak pelaksana (BPN) akan mengkoreksi akta dan data-data yang di upload oleh PPAT dan yang disetujui oleh pihak jasa keuangan (Bank). Data yang diajukan PPAT tersebut sudah sesuai atau tidak. Jika tidak sesuai pihak pelaksana (BPN) berhak mengajukan sanggahan, misalnya karena hasil scan yang buram yang diajukan dan salah upload data. Sanggahan yang di sampaikan oleh pihak pelaksana (BPN) di 
sampaikan melalui email masing-masing baik PPAT atau Jasa Keuangan tergantung dari pihak yang mana salah meng upload data dan yang di nyatakan tidak sesuai oleh pihak pelaksana (BPN). Kemudian mereka yang dinyatakan salah meng upload data, maka melakukan perbaikan data tersebut dan kembali di upload. Jika pihak yang dinyatakan salah upload data oleh pihak pelaksana (BPN) tidak merubah atau membenarkan data yang dinyatakan salah dan diberikan waktu 4 (empat) hari untuk mengubah, tetapi jika tidak diindahkan, maka sistem otomatis akan ditutup dan perbaikan tidak bisa dilakukan. Kemudian jika tidak ada permasalahan data lagi, hak tanggungan tersebut langsung terbit dalam waktu 7 (Tujuh).

Jika pihak pelaksana (BPN) tidak melakukan pemeriksaan sampai pada hari ke-7 (tujuh) (14 Ayat 1) dan hasil Pelayanan HT-el diterbitkan oleh Sistem HT-el, dianggap memberikan persetujuan dan/atau pengesahan. Pihak pelaksana (BPN) bertanggung jawab secara administratif atas hasil Pelayanan HT-el (Pasal 14 Ayat 2).

Setelah selesainya proses pembayaran dari pihak jasa keuangan (bank), maka 7 (tujuh) hari setelah pembayaran tersebut, keluarlah sertipikat hak tanggungan elektronik. Pihak Bank atau Jasa keuangan diberikan waktu 30 (tiga puluh) hari untuk mengecek kebenaran sertipikat HT-el tersebut dan mengajukan perbaikan terhadap sertipikat HT-el. Dokumen Hak Tanggungan yang dapat diperbaiki meliputi peringkat, Nomor Akta, Pemegang Hak, Penunjuk, Nilai Partial, Jenis dan Nomor Hak dan Benda Lain, bentuk catatan perbaikan ini juga dicetak dan ditempel pada Catatan Pembebanan Dalam Sertipikat Hak Atas Tanah Yang Menjadi Objek Jaminan.

Pasal 1 Angka 8 Peraturan Menteri Agraria Dan Tata Ruang/ Kepala Badan Pertanahan Nasional Republik Indonesia Nomor 1 Tahun 2021 Tentang Sertipikat Elektronik disebut Sertipikat-El adalah Sertipikat yang diterbitkan melalui sistem elektronik dalam bentuk dokumen elektronik. Dokumen Elektronik adalah setiap informasi elektronik yang dibuat, diteruskan, dikirimkan, diterima, atau disimpan dalam bentuk analog, digital, elektromagnetik, optikal, atau sejenisnya, yang dapat dilihat, ditampilkan, dan/atau didengar melalui komputer atau Sistem Elektronik, termasuk tetapi tidak terbatas pada tulisan, suara, gambar, peta, rancangan, foto atau sejenisnya, huruf, tanda, angka, kode akses, simbol atau perforasi yang memiliki makna atau arti atau dapat dipahami oleh orang yang mampu memahaminya (Pasal 1 angka 2 Permen ATR/BPN Nomor 1 Tahun 2021 tentang sertipikat elektronik). Kemudian pada Pasal 12 Ayat 1, menyebutkan bahwa Tanah yang sudah ditetapkan haknya menjadi hak atas tanah, hak pengelolaan, hak milik atas satuan rumah susun, hak tanggungan atau tanah wakaf didaftar melalui Sistem Elektronik dan diterbitkan Sertipikat-el. Pada Ayat 2, menyebutkan, kumpulan Sertipikat-el yang tersimpan di Pangkalan Data secara berurutan sesuai edisinya sebagai riwayat pendaftaran tanah menjadi buku tanah elektronik. Sertipikat Hak Tanggungan Elektronik yang selanjutnya disebut Sertipikat HT-el adalah tanda bukti hak tanggungan berbentuk Dokumen Elektronik yang berisi informasi hak tanggungan.

Sesuai dengan Pasal 15 Peraturan Menteri Agraria Dan Tata Ruang/ Kepala Badan Pertanahan Nasional Republik Indonesia Nomor 5 Tahun 2020 Tentang Pelayanan Hak Tanggungan Terintegrasi Secara Elektronik, menyebutkan Hasil Pelayanan HT-el berupa Dokumen Elektronik yang diterbitkan oleh Sistem HT-el, meliputi : Sertipikat HT-el, Catatan Hak Tanggungan pada buku tanah hak atas tanah atau Hak Milik Atas Satuan Rumah Susun, dan Catatan Hak Tanggungan pada Sertipikat Hak Atas Tanah atau Hak Milik Atas Satuan Rumah Susun.

Pencatatan Hak Tanggungan pada buku tanah hak atas tanah atau Hak Milik Atas Satuan Rumah Susun sebagaimana dimaksud pada ayat (1) huruf b dilakukan pada Buku Tanah Elektronik oleh Kepala Kantor Pertanahan atau pejabat yang diberi kewenangan. Pencatatan Hak Tanggungan pada Sertipikat Hak Atas Tanah atau Hak Milik Satuan Rumah Susun dilakukan oleh Kreditor pada Sertipikat Hak Atas Tanah atau Hak Milik Satuan Rumah Susun yang dijaminkan menjadi satu kesatuan dengan Sertipikat Hak Atas Tanah atau Hak Milik Satuan Rumah Susun. Hasil Pelayanan HT-el disampaikan kepada Kreditor melalui Sistem HT-el dan/atau melalui Domisili Elektronik. Hasil Pelayanan HT-el sebagaimana dimaksud dalam Pasal 15 disahkan dengan Tanda Tangan Elektronik oleh Kepala Kantor Pertanahan atau pejabat yang diberi kewenangan, untuk menjaga keutuhan dan keautentikan Dokumen Elektronik.

Hak Tanggungan Elektronik saat ini mulai berlaku awal januari tahun 2020 sampai saat ini efektif. Perubahan Hak tanggungan manual menjadi hak tanggungan elektronik memudahkan kinerja jasa keuangan (Bank) dalam mengajukan permohonan hak tanggungan, yang mana diawal proses hak tanggungan manual banyak prosedurnya, tetapi dengan hadirnya hak tanggungan secara elektronik, maka prosedurnya menjadi lebih sederhana, sehingga memudahkan jasa keuangan dalam mengajukan permohonan hak tanggungan. Di samping itu, efektif dari segi waktu dan meminimalisir biaya dalam pengurusan dalam HT-el tersebut. Disamping pihak jasa keuangan (Bank) dan Pihak Pelaksana (BPN) menyatakan efektif adanya suatu hak tanggungan secara elektronik baik dari segi proses dan waktu, hal ini ditambah pernyataan dari beberapa PPAT yang wilayah kerja di kabupaten Buleleng yang menyatakan bahwa sudah efektif hak tanggungan secara elektronik di Kabupaten Buleleng. Walapun sudah demikian efektif dinyatakan oleh beberapa informan, menurut peneliti jika kaitkan dengan Teori Efektivitas hukum, 
maka suatu hukum dapat dikatakan efektif apabila perilaku warga masyarakat sesuai dengan hukum yang berlaku atau diputuskan atau dikehendaki oleh hukum maka dapat dikatakan bahwa hukum yang bersangkutan efektif. Menurut teori yang di kemukakan Lawrence M. Friedman, bahwa efektif atau tidaknya suatu penegakan hukum tergantung pada tiga elemen penting yaitu sebagai berikut (Friedman, 2011).

Pertama, subtansi hukum. Aturan, norma, dan pola perilaku manusia yang berada dalam system tersusun dari peraturan-peraturan dan ketentuan-ketentuan yang dapat dikehendaki oleh hukum. Hak Tanggungan secara Elektronik (HT-el) termuat dalam Peraturan Menteri Peraturan Menteri ATR/BPN RI Nomor 5 tahun 2020 Tentang Pelayanan Hak Tanggungan Terintegritas Secara Elektronik. Isi dari peraturan perundang-undangan ini sudah baik dan terbukti bahwa pihak pengguna dari HT-el tidak salah menafsirkan arti Peraturan Menteri tersebut. Jelas aturan yang mengatur mengenai HT-el tersebut. Bagi Pelaksana (BPN), Pihak jasa Keuangan (Bank), Pihak PPAT menyatakan bahwa sudah efektif, sehingga menurut peneliti dari segi isi aturan nya sudah efektif dan jelas, serta tidak menimbulkan multitafsir dari permen tersebut.

Kedua, struktur hukum (aparat penegak hukum). Struktur adalah suatu institusionalisasi ke dalam entitas-entitas hukum, berkaitan dengan aparatur penegak hukum berupa system tata kerja dan pelaksana dari ketentuan yang diatur dalam substansi hukum, seperti pengadilan tingkat pertama, tingkat banding, dan tingkat kasasi. Termasuk juga dalam tatanan kelembagaan dan kinerja lembaga, struktur hukum tidak hanya meliputi aparat penegak hukum saja akan tetapi meliputi juga sarana dan prasarana yang mendukung aparat pelaksana hukum tersebut. Pengguna HT-el sudah diadakan suatu sosialisasi, cara menggunakan dari HT-el, baik pihak BPN, PPAT dan Jasa Keuangan (Bank) yang menggunakan dari HT-el tersebut. Peraturan Menteri ATR/BPN Nomor 5 Tahun 2020 tentang Pelayanan Hak Tanggungan Terintegritas Secara Elektronik disambut baik oleh pihak BPN Buleleng, terbukti bahwa sebelum pelaksanaan proses HT-el di Kantor Pertanahan Kabupaten Buleleng, terlebih pihak BPN dahulu menyiapkan berbagai keperluan baik dari sarana dan prasarana, sumber daya manusianya yang akan dilatih dalam menggunakan HT-el. Selain diadakannya pelatihan bagi pihak BPN (Pelaksana), Pihak BPN Kabupaten Buleleng sudah menerapkan aturan Permen ATR/BPN Nomor 5 Tahun 2020 tentang pelayanan Hak Tanggungan Terinegritas secara eletronik dan sudah sejak januari tahun 2020. Saat ini pihak BPN (Pelaksana) Kabupaten Buleleng tidak menerima lagi permohonan hak tanggungan secara manual, biarpun hal tersebut kondisinya jaringan bermasalah dari HT-el tersebut, tetapi tetap dilaksanakan permohonan secara HT-el (Hasil Wawancara Yogi Astuti, bagian Penata Pertanahan pertama seksi penetapan hak dan pendaftaran Kantor Pertanahan Kabupaten Buleleng : 2021). Menurut Peneliti dari struktur hukum (penegakan hukum) dalam menerapkan Permen ATR/BPN Nomor 5 Tahun 2020 tentang pelayanan Hak Tanggungan Terinegritas secara eletronik sudah berjalan efektif .

Ketiga, kultur (budaya masyarakat). Kultur hukum adalah elemen sikap dan nilai sosial, kultur hukum mengacu pada bagian-bagian yang ada pada kultur umum, adat kebiasaan, opini, cara bertindak dan berpikir yang mengarah pada kekuatan-kekuatan sosial menuju atau menjauh dari hukum dan caracara tertentu. Melihat penerapan pengurusan Ht-el di kantor pertanahan selaku pelaksana dan pengguna dari jasa keuangan dan PPAT menyampaikan bahwa Ht-el tersebut sudah cukup efektif, namun masih terdapat kendala seperti misalnya hasil scan buram, kesalahan teknis pengguna dan setiap hari ada yang keliru dalam mengupload data. Menurut peneliti, kalau mengkaji dari budaya hukum masih dapat dikatakan belum efektif, karena masih terdapat kendala-kendala yang terjadi dalam proses pengurusan HT-el seperti ada yang salah mengupload data, hal ini merupakan budaya hukum pengguna HT-el masih perlu di berikan suatu pemahaman dan ke cermatan terhadap pengguna dalam meng upload dokumendokumen yang di perlukan dalam pengurusan HT-el. Tidak dapat di pungkiri karena sebelum adanya HTel tersebut, pengurusan Hak Tanggungan masih secara manual yaitu pihak pengguna langsung datang ke BPN untuk pengurusan Hak tanggungan tersebut. Perubahan ini merupakan perubahan budaya hukum, yang dulunya pengurusan HT secara manual kemudian berkembang dan berubah menjadi budaya hukum yang secara elektronik. Dahulu sistem manual terlalu panjang prosedurnya dan sekarang sistem online tersebut mengefesienkan dari pengurusan hak tanggungan tersebut, sehingga asas sederhana dalam pendaftaran tanah bisa terlaksana yang artinya agar ketentuan-ketentuan pokok maupun prosedur dengan mudah dapat dipahami oleh pihak-pihak yang berkepentingan, terutama para pemegang hak atas tanah. Budaya hukum tersebut memegang peranan penting dalam efektifnya sebuah aturan hukum, sehingga diperlukan suatu adaptasi dalam penggunaan HT- el tersebut.

Setelah hapusnya utang yang dijamin dengan Hak Tanggungan, maka Kantor Pertanahan mencoret catatan Hak Tanggungan tersebut pada buku-tanah hak atas tanah dan sertipikatnya. Dengan hapusnya Hak Tanggungan, sertipikat Hak Tanggungan yang bersangkutan ditarik dan bersama-sama buku-tanah Hak Tanggungan dinyatakan tidak berlaku lagi oleh Kantor Pertanahan (Pasal 22 Ayat 2 Undang-Undang Nomor 4 Tahun 1996 Tentang Hak Tanggungan Atas Tanah Beserta Benda-Benda Yang 
Berkaitan Dengan Tanah). Permohonan pencoretan (Roya) sebagaimana diajukan oleh pihak yang berkepentingan dengan melampirkan sertipikat Hak Tanggungan yang telah diberi catatan oleh kreditor bahwa Hak Tanggungan hapus karena piutang yang dijamin pelunasannya dengan Hak Tanggungan itu sudah lunas, atau pernyataan tertulis dari kreditor bahwa Hak Tanggungan telah hapus karena piutang yang dijamin pelunasannya dengan Hak Tanggungan itu telah lunas atau karena kreditor melepaskan Hak Tanggungan yang bersangkutan. Kantor Pertanahan melakukan pencoretan catatan Hak Tanggungan menurut tata cara yang ditentukan dalam peraturan perundang-undangan yang berlaku dalam waktu 7 (tujuh) hari kerja terhitung sejak diterimanya permohonan (Pasal 22 Ayat 8 UU No 4 Tahun 1996 Tentang Hak Tanggungan Atas Tanah Beserta Benda-Benda Yang Berkaitan Dengan Tanah).

Pencoretan (Roya) yang dilaksanakan di kantor pertanahan Kabupaten Buleleng dilakukan masih dengan cara manual dan dilakukan dengan cara elektronik. Kalau Roya manual masih diterapkan terhadap hak tanggungan yang dahulu diterapkan secara proses manual dan roya elektronik diberlakukan terhadap HT-el. Roya elektronik menggunakan kode, dan tidak membaca hak tanggungan secara manual. Oleh karena itu disesuaikan, jika hak tanggungan sebelumnya dilakukan prosesnya secara manual maka proses royanyapun dilakukan secara manual begitupula dengan HT-el, jika hak tanggungan dilakukan secara elektronik, maka proses royanya pun menggunakan roya elektronik. Roya elektronik menggunakan kode dan roya elektronik hanya membaca kode yang ada pada hak tanggungan secara elektronik

Untuk pengajuan roya secara manual dilakukan pengajuan oleh debitur ke kantor pertanahan, jika pihak pemohon (debitur) sudah melunasi hutangnya kepada pihak bank (kreditur). Syarat pihak pemohon secara manual dalam pengajuannya yaitu : membawa sertipikat hak milik, sertipikat hak tanggungan, surat permohonan roya, surat pelunasan dari pihak bank (jasa keuangan). Kalau roya HT-el, yang melakukan pengajuan adalah pihak jasa keuangan (kreditur/bank) yang mengajukan melalui sistem di kantor pertanahan dan menggunakan akun bank (jasa keuangan) sebagai pengguna HT-el tersebut. Syarat pengajuan roya elektronik yang diajukan pihak jasa keuangan yaitu : pihak jasa keuangan cukup scan dan mengupload sertipikat dan surat formulir pemasangan roya. Pihak pelaksana (BPN) tidak melakukan sanggahan ataupun perbaikan pada proses pengajuan roya HT-el tersebut. Proses roya elektronik terbit dalam 1 (Satu) hari kerja, pihak jasa keuangan (bank) mengajukan proses roya kemudian pihak jasa keuangan membayar dan pada saat itu langsung terbit hasil roya yang diajukan tersebut.

\section{Pembahasan}

Pasal 4 ayat (1) UUPA menjelaskan bahwa Atas dasar hak menguasai dari Negara sebagai yang dimaksud dalam Pasal 2 ditentukan adanya macam-macam hak atas permukaan bumi, yang disebut tanah, yang dapat diberikan kepada dan dipunyai oleh orang baik sendiri maupun bersama-sama dengan orang lain serta badan-badan hukum (Irman et al., 2021; Kurniawan, 2019). Pasal tersebut memberi wewenang untuk mempergunakan tanah yang bersangkutan demikian pula tubuh bumi dan air serta ruang yang ada di atasnya, sekedar diperlukan untuk kepentingan yang langsung berhubungan dengan penggunaan tanah itu dalam batas-batas menurut undang-undang ini dan peraturan-peraturan hukum lain yang lebih tinggi (Kusumawati et al., 2016; Waryanta, 2016). Hak atas tanah bersumber dari hak menguasai dari negara atas tanah dapat diberikan kepada perseorangan baik warga negara Indonesia mapupun warga negara asing, sekelompok orang secara bersama-sama, dan badan hukum baik badan hukum privat maupun badan hukum public. Wewenang yang dipunyai oleh pemegang hak atas tanah terhadap tanahnya dibagi menjadi 2.

Pertama, wewenang Umum. Wewenang yang bersifat umum yaitu pemegang hak atas tanah mempunyai wewenang untuk menggunakan tanahnya, termasuk juga tubuh bumi, air dan ruang yang ada di atasnya sekadar diperlukan untuk kepentingan yang langsung berhubungan dengan penggunaan tanah itu dalam batas-batas menurut UUPA dan peraturan-peraturan hukum lain (Ramadhani et al., 2019; Widiarti, 2018). Kedua, wewenang Khusus. Wewenang yang bersifat khusus yaitu pemegang hak atas tanah mempunyai wewenang untuk menggunakan tanahnya sesuai dengan macam hak atas tanahnya (C. B. Pranoto, 2017; Waryanta, 2016). Misalnya wewenang pada tanah Hak Milik adalah dapat untuk kepentingan pertanian dan atau mendirikan bangunan, Hak Guna Bangunan (HGB) untuk mendirikan bangunan, Hak Guna Usaha (HGU) untuk kepentingan pertanian, perkebunan, perikanan dan peternakan. Pada Pasal 24 (1) Kepala Kantor Pertanahan dapat menolak Pelayanan HT-el, antara lain, terdapat sita dan/atau blokir dalam jangka waktu proses Pelayanan HT-el dan terdapat alasan lain berdasarkan ketentuan peraturan perundang-undangan. Penolakan permohonan Pelayanan HT-el diberitahukan kepada Kreditor melalui Sistem HT-el, Domisili Elektronik dan/atau media elektronik lainnya (Pasal 24 (2)).

Kendala yang di hadapi oleh ketiga pengguna Hak tanggungan secara elektronik yaaitu sebagai berikut. Pertama, pihak PPAT melakukan pengecekan sertifikat yang akan di bebankan hak tanggungan. 
Pada proses pengecekan tersebut sering terjadi permasalahan pada jaringan. Kedua, pada saat pengecekan sertifikat, data yang dimiliki oleh Badan pertanahan belum ter update dengan data yang ada di Badan Pertanahan nasional (Pusat). Jika pihak Badan Pertanahan yang ada di daerah salah meng input data dan berbeda dengan data yang di input oleh PPAT dan BPN Daerah, maka data tersebut di kembalikan oleh BPN pusat. Upaya PPAT untuk memperbaiki hal tersebut, PPAT mendatangi langsung ke badan pertanahan daerah buleleng dan pihak BPN Buleleng kemudian memperbaikinya. Ketiga, kesalahan teknis dan kurang cermatnya pihak karyawan PPAT dalam meng input data pengecekan sertipikat dan kemudian oleh pihak karyawan PPAT di print data tersebut. Karyawan harus cermat dan teliti agar tidak terjadi kesalahan (Ahmad et al., 2019; Firmansyah \& Aima, 2020; Mahriani, 2018). Artinya sudah di setujui data tersebut oleh pihak PPAT, kemudian setelah di print tersebut jika ditemukan kesalahan terhadap data yang di print tersebut, maka pihak Badan pertanahan kabupaten buleleng tidak bisa memperbaiki, kecuali dengan upaya pendaftaran ulang pengecekan sertipikat.

Keempat, Pihak PPAT sudah mengirim data APHT (Akta Pemberian Hak Tanggungan) kepada pihak bank dan kemudian pihak bank yang bertugas untuk HT-el terlambat mendaftarkan ke Badan Pertanahan Nasional karena alasan terentu, maka jika dilihat dari ketentuan yang ada lewat dari 7 (tujuh) hari pendaftaran tersebut. Pada Ketentuan ini diatur pada Pasal 40 Ayat PP 24 tahun 1997 tentang pendaftaran tanah, yang menyatakan bahwa selambat-lambatnya 7 (tujuh) hari kerja sejak tanggal ditandatanganinya akta yang bersangkutan, PPAT wajib menyampaikan akta yang dibuatnya berikut dokumen-dokumen yang bersangkutan kepada kantor pertanahan untuk di daftar. Upaya untuk alasan yang sesuai dengan kendala tersebut, pihak BPN. Kelima, Server terkait HT-el yang sering terjadi gangguan dan pihak BPN Buleleng sulit untuk memberikan upaya untuk membenahi, karena servernya pusat yang mengendalikan. Server yang sering mengalami gangguan akan menyulitkan kegiatan kerja (Dwihartanti \& Faizah, 2018; Molly et al., 2017).

Keenam, pihak pengguna tidak melihat email masuk. Maka server di tutup otomatis 4 (empat) hari kerja semenjak di daftarkan HT-el tersebut. Upayanya melakukan pendaftaran kembali. Ketujuh, Sertipikat terlambat terbit. Pihak BPN Buleleng melakukan upaya langsung menghubungi ke pusat untuk menanyakan sertipikat tersebut yang terkendala terbit untuk di perbaiki. Kedelapan, Sering terjadi kesalahan, seperti salah upload dan belum tanda tangan, serta hasil scan yang buram dari pihak PPAT, upaya yang dilakukan pihak BPN (Pelaksana) melakukan sanggahan kepada pihak pengguna tersebut. Kesembilan, Hak tanggungan yang nilainya besar dan Hak tanggungan yang tidak bermasalah atau tidak ada sanggahan (tidak ada penolakan) terkadang di tutup oleh sistem (permasalahan di sistem), maka upaya yang dilakukan oleh pihak BPN mengajukan keadaan memaksa (Force Majeur) ke sistem dengan di lengkapi surat pernyataan alasan tidak diperbaiki dari Bank, PPAT dan berita acara kepala Kantor Pertanahan Buleleng dan pengguna tidak perlu membayar kembali untuk pendaftaran HT-el tersebut.

Kesepuluh, Kesalahan teknis dari pihak Bank, seperti pihak karyawan bank lupa nomor berkas dan kode sertipikat, upaya yang dilakukan meningkatkan kecermatan pihak karyawan Bank yang di bagian pendaftaran Ht-el. Kesebelas, Terkadang pihak jasa keuangan lain seperti lembaga Perkreditan Desa (LPD) dan Koperasi tidak ingin mendaftarkan akun sebagai pengguna HT-el, sehingga pihak jasa keuangan tidak dapat memberikan kredit dengan jaminan hak tanggungan secara elektronik. Kedua belas, Banyaknya syarat untuk mendaftarkan akun hak tanggungan secara elektronik, sehingga pihak yang pengguna seperti jasa keuangan dengan modal jumlah kecil enggan untuk mendaftarkan akun sebagai pengguna HT-el. Ketigabelas, Pada kantor pertanahan Kabupaten Buleleng terkait dengan waktu perbaikan berkas HT-el yaitu 4 (Empat) hari kalender, apabila PPAT terlambat untuk memperbaikinya ataupun jaringan eror atau sistem eror pada saat perbaikan, maka tentu akan mempengaruhi pendaftaran HT-el, sehingga akan batal dan PPAT diharuskan untuk membayar PNBP kembali. Keempatbelas, Terhadap roya masih ada dua cara yang dilakukan, yaitu roya manual dan roya elektronik, sehingga terjadi double cara dalam roya sertipikat hak tanggungan. Kelimabelas, Keterlambatan karena sistem jaringan dan server HT-el mempengaruhi kurang baiknya pelayanan kepada masyarakat (Dasuki, 2017; Jaroji et al., 2017).

Kendala yang dihadapi dalam pengurusan HT-el secara umumnya di sistem atau server yang mengatur terkait HT-el dan pada pihak pengguna HT-el, hal ini terbukti masih saja terkendala sering terjadi kesalahan dalam upload data. Upaya dalam kendala tersebut adalah ada pada server yang harus memadai dan SDM (Sumber daya Manusia) yang mengoperasikan dapat menggunakan dengan baik (Ahmad et al., 2019; Asih Niati et al., 2019; Ferawati, 2017; Sari, 2015). Asas-asas pendaftaran tanah tercantum di dalam Pasal 2 Peraturan Pemerintah Nomor 24 Tahun 1997 tentang pendaftaran tanah, serta terdapat penjelasannya juga sebagai berikut. Pertama, Asas aman. Asas ini dimaksudkan untuk menunjukkan bahwa pendaftaran tanah perlu diselenggarakan secara teliti dan cermat sehingga hasilnya dapat memberikan jaminan kepastian hukum sesuai tujuan pendaftaran tanah itu sendiri (Ernanda et al., 2021; Susilaningsih, 2019). Kedua, Asas Terjangkau. Asas ini dimaksudkan keterjangkauan bagi pihak- 
pihak yang memerlukan, khususnya dengan memerhatikan kebutuhan dan kemampuan golongan ekonomi lemah (Bimantara et al., 2019; H. Pranoto, 2020). Pelayanan yang diberikan dalam rangka penyelenggaraan pendaftaran tanah harus bisa terjangkau oleh pihak yang memerlukan. Ketiga, Asas Mutakhir. Asas ini dimaksudkan kelengkapan yang memadai dalam pelaksanaannya dan kesinambungan dalam pemeliharaan datanya. Data yang tersedia harus menunjukkan keadaan yang mutakhir (Badriyah, 2016; Jayanti \& Darmawan, 2018). Untuk itu diikuti kewajiban mendaftar dan pencatatan perubahanperubahan yang terjadi di kemudian hari. Keempat, Asas Terbuka. Asas ini dimaksudkan agar masyarakat dapat mengetahui atau memperoleh keterangan mengenai data fisik dan data yuridis yang benar setiap saat di Kantor Pertanahan Kabupaten atau Kota.

Selain asas tersebut diatas, asas pelayanan publik yang dipertimbangkan dalam Peraturan Menteri ATR/BPN Kepala BPN Nomor 5 Tahun 2020 dalam penyelenggara HT-el tidak secara keseluruhan terdapat 3 (tiga) asas yang menjadi komponen evaluasi HT-el yang akan dilakukan yaitu sebagai berikut. Pertama, Keterbukaan Berdasarkan penjelasan Pasal 4 huruf (h) Undang-Undang Nomor 25 Tahun 2019 keterbukaan merupakan kemudahan dalam melakukan akses dan memperoleh informasi mengenai pelayanan yang diinginkan oleh penerima pelayanan peneliti akan melakukan evaluasi keterbukaan dari segi sistem mekanimse dan prosedur HT-el. Kedua, Ketepatan waktu Penyelesaian setiap jenis pelayanan dilakukan tepat waktu seusai dengan standar pelayanan. Ketetapan waktu suatu komponen yang sangat penting demi meningkatkan kepercayaan masyarakat terhadap layanan HT-el. Keterlambatan waktu penyelesaian seharusnya tidak terjadi lagi dimana Peralihan dari HT Konvesioanl menjadi elektronik sudah berjalan secara otomatis. Ketiga, Kecepatan, kemudahan, dan keterjangkauan Kecepatan suatu layaana akan diperloleh jika pelaksanaanya memiliki sumber daya manusia yang kompetensi dengan jumlah yang memadai seusai kebutuhan penyelenggara layanan. Ketentuan persyaratan seharusnya dapat dengan mudah dipahami oleh berbagai pihak yang berkepentingan. Selain itu, keterjangkauan biaya/tarif yang telah ditetapkan besarnya harus sesuai ketentuan yang telah ditetapkan secara keseluruhan akan meningkatkan rasa kepercayaan bagi masyarakat. Jika sudah terlaksana asas-asas tersebut dalam pendaftaran tanah khususnya mengatur mengenai HT-el, jelas akan memberikan jaminan kepastian hukum terhadap hak tanggungan elektonik tersebut.

\section{SIMPULAN}

Efektivitas Pengurusan Hak Tanggungan Elektronik di Kantor Pertanahan Kabupaten Buleleng menyatakan bahwa sudah efektif. Substansi hukum (perundang-undangan) adalah Peraturan Menteri Peraturan Menteri ATR/BPN RI Nomor 5 tahun 2020 Tentang Pelayanan Hak Tanggungan Terintegritas Secara Elektronik. Isi dari peraturan perundang-undangan ini sudah baik dan terbukti bahwa pihak pengguna dari HT-el tidak salah menafsirkan arti Peraturan Menteri tersebut. Struktur hukum (aparat penegak hukum), Pengguna HT-el sudah diadakan suatu sosialisasi, cara menggunakan dari HT-el, baik pihak BPN, PPAT dan Jasa Keuangan (Bank) yang menggunakan dari HT-el tersebut. Budaya hukum masih dapat dikatakan belum efektif terkait pengurusan HT-el, karena masih terdapat kendala-kendala yang terjadi dalam proses pengurusan HT-el seperti ada yang salah mengupload data. Kendala yang dihadapi dalam pengurusan HT-el secara umumnya di sistem atau server yang mengatur terkait HT-el dan pada pihak pengguna HT-el.

\section{DAFTAR PUSTAKA}

Adi Widjaja, A. R. B., \& Winarno, B. (2018). Pelaksanaan Eksekusi Jaminan Hak Tanggungan Dalam Penyelesaian Kredit Macet Di Lembaga Perbankan. Jurnal Ilmiah Pendidikan Pancasila Dan Kewarganegaraan, 3(1). https://doi.org/10.17977/um019v3i12018p001.

Ahmad, Y., Tewal, B., Taroreh, R. N., Ekonomi, F., Manajemen, J., \& Ratulangi, U. S. (2019). Pengaruh Stres Kerja, Beban Kerja, Dan Lingkungan Kerja Terhadap Kinerja Karyawan Pada Pt. Fif Group Manado. Jurnal EMBA: Jurnal Riset Ekonomi, Manajemen, Bisnis Dan Akuntansi, 7(3), 2811-2820. https://doi.org/10.35794/emba.v7i3.23747.

Arta, I. K. K. S., \& Qurbani, I. D. (2021). Kepastian Hukum Atas Penunjukan Desa Pakraman Di Provinsi Bali Sebagai Subjek Hak Pemilikan Bersama (Komunal) Atas Tanah Sesuai Dengan Pasal II Ayat 1 Konversi UUPA. Jurnal IUS Kajian Hukum Dan Keadilan, 9. https://doi.org/10.29303/ius.v9i1.778.

Asih Niati, A., Soelistiyono, T., \& Ariefiantoro. (2019). Pengembangan Kemampuan Sumber Daya Manusia melalui Pelatihan Komputer Microsoft Office Excel untuk Meningkatkan Kinerja Perangkat Desa Mranggen. E-Dimas: Jurnal Pengabdian Kepada Masyarakat, 10(1). https://doi.org/10.26877/edimas.v10i1.3557.

Badriyah, S. M. (2016). Problematika Pembebanan Hak Tanggungan Dengan Objek Tanah Yang Belum 
Bersertipikat. Masalah-Masalah Hukum, 45(3). https://doi.org/10.14710/mmh.45.3.2016.173180.

Basit, A. (2016). Jaminan Kredit Pemilikan Rumah dengan Perjanjian Pemberian Jaminan dan Kuasa. Lambung Mengkurat, 1(1). https://doi.org/10.32801/lamlaj.v1i1.2.

Basuki, R. A. (2015). Pengaruh Mekanisme Screening, Pemberian Insentif Dan Hubungan Sosial Bank Dengan Nasabah Dalam Mengurangi Masalah Agency Kredit Pada Bank Perkreditan Rakyat Di Indonesia. Jurnal Siasat Bisnis, 17(2). https://doi.org/10.20885/jsb.vol17.iss2.art7.

Bimantara, R., Mulyati, E., \& Ikhwansyah, I. (2019). Penerapan Konsinyasi Terhadap Objek Yang Sudah Dijaminkan Melalui Hak Tanggungan. Jurnal IUS Kajian Hukum Dan Keadilan, 7(2). https://doi.org/10.29303/ius.v7i2.645.

Catur, B. (2014). Pengamanan Pemberian Kredit Bank Dengan Jaminan Hak Guna Bangunan. Jurnal Cita Hukum, 2(2). https://doi.org/10.15408/jch.v1i2.1468.

Dasuki, D. (2017). Strategi Membangun Model Pelayanan Sosial Berbasis Masyarakat Melalui Wahana Kesejahteraan Sosial Berbasis Masyarakat (Wksbm) Di Yogyakarta. Sosio Konsepsia: Jurnal Penelitian Dan Pengembangan Kesejahteraan Sosial, https: //doi.org/10.33007/ska.v11i2.595.

Dwihartanti, M., \& Faizah, N. N. (2018). Pentingnya Penguasaan Bahasa Inggris Bagi Pelaksanaan Tugas Rutin Sekretaris. Efisiensi - Kajian Ilmu Administrasi, $15(1)$. https: //doi.org/10.21831/efisiensi.v15i1.24483.

Ernanda, D., Istislam, I., \& Yuliati, Y. (2021). Penerapan asas-asas umum pemerintahan yang baik dalam penyelesaian sengketa tanah hak milik. Cakrawala Hukum, 12(1). https://doi.org/10.26905/idjch.v12i1.4226.

Fahmi, H. R., Setia, T. A., Negara, E. S., \& Kawuryan. (2020). Dasar Pertimbangan Penetapan Nilai Limit Obyek Lelang Eksekusi Hak Tanggungan. Jurnal Ilmiah Pendidikan Pancasila Dan Kewarganegaraan, 4(2). https://doi.org/10.17977/um019v4i2p310-320.

Ferawati, A. (2017). Pengaruh Lingkungan Kerja Dan Disiplin Kerja Terhadap Kinerja Karyawan. Jurnal Dimensi, 7(2). https://doi.org/10.33373/dms.v7i2.1702.

Firmansyah, A., \& Aima, H. (2020). Pengaruh pelatihan, kompensasi, dan motivasi kerja terhadap kinerja karyawan. Journal FEB Unmul: Kinerja, 17(2), 182-185. https: //doi.org/10.29264/jkin.v17i2.7050.

Friedman, L. M. (2011). Sistem Hukum Perspektif Ilmu Sosial. Nusa Media.

Ginting, S. L. B., \& Permana, A. A. (2018). Hybrid Classifier System: Support Vector Machines Dikombinasikan dengan K-Nearest Neighbors untuk Menentukan Kelayakan Nasabah Bank dalam Pengajuan Kredit. Jurnal Sistem Komputer, 7(1). https://doi.org/10.34010/komputika.v7i1.1402.

Guntoro, J., Kontesa, E., \& Sauni, H. (2020). Tinjauan Yuridis Pendaftaran Hak Tanggungan Dalam Pelayanan Hak Tanggungan Terintegrasi Secara Elektronik. Jurnal Ilmu Hukum, 10(2). https://doi.org/10.33369/j_bengkoelenjust.v10i2.13806.

Hurlock, A. N. \& Y. R. (2009). Metode Pengembangan Sosial Emosional. Universitas Terbuka.

Irman, Adhayanto, O., Sari, R. K., \& Suryadi. (2021). Analisis Yuridis Terhadap Status Hak Kepemilikan Permukiman Penduduk Di Atas Air. Jurnal Hukum Dan Pembangunan, 51(2). https: //doi.org/10.21143/jhp.vol51.no2.3057.

Jaroji, J., Kurniati, R., \& Agustiawan, A. (2017). Image Processing dan Artifical Neural Network Untuk Mengenali Nomor Induk Kependudukan Pada KTP Sebagai Pendukung Layanan Mandiri di Kantor Desa. Digital Zone: Jurnal Teknologi Informasi Dan Komunikasi, 8(2). https://doi.org/10.31849/digitalzone.v8i2.632.

Jayanti, O., \& Darmawan, A. (2018). Pelaksanaan Lelang Tanah Jaminan yang Terikat Hak Tanggungan. Kanun: Jurnal Ilmu Hukum, 20(3). https: //doi.org/10.24815/kanun.v20i3.11830.

Kamaluddin, N., \& Haryati, M. A. (2020). Evaluasi Sistem Pengendalian Intern Terhadap Pemberian Kredit Bumdes Bangun Bersama. Monex: Journal Research Accounting Politeknik Tegal, 9(1). https://doi.org/10.30591/monex.v9i1.1772.

Kurniawan, F. (2019). Aspek Hukum Pemberian HPL Atas Bidang Tanah Yang Telah Dikuasai, Diduduki Atau Digarap Oleh Warga. Jurnal Fakultas Hukum Universitas Khatolik Darma, 4(2). https: //doi.org/10.37477/sev.v4i2.192.

Kusumawati, A., Santosa, L. W., \& Hadisusanto, S. (2016). Kajian Status Trofik Sebagai Dasar Strategi Penataan Lingkungan di Telaga Merdada. Majalah Geografi Indonesia, 24(1). https: //doi.org/10.22146/mgi.13338.

Mahriani, E. (2018). Pengaruh Stres Dan Disiplin Kerja Karyawan Terhadap Kepuasan Dan Kinerja Karyawan Pt. Bank Perkreditan Rakyat (Bpr) Mitrathama Arthabuana Di Kabupaten Banjar. AtTaradhi: Jurnal Studi Ekonomi, 9(1). https://doi.org/10.18592/at-taradhi.v9i1.2120. 
Molly, B., Tanaamah, A. R., \& Sitokdana, M. N. N. (2017). Analisis Kinerja Sistem Informasi dan Teknologi Informasi untuk Menunjang Kinerja Karyawan Menggunakan Framework IT Balanced Scorecard (Studi Kasus pada Wi-Fi Universitas Kristen Satya Wacana). Jurnal Teknologi Informasi Dan Ilmu Komputer, 4(4). https://doi.org/10.25126/jtiik.201744499.

Munawaroh. (2011). Peranan Pengendalian Internal dalam Menunjang Efektivitas Sistem Pemberian Kredit Usaha Kecil dan Menengah (Studi kasus di Koperasi Pegawai BRI Cabang Kediri). Jurnal Managemen Dan Kewirausahaan, 13(1). https: //doi.org/10.9744/jmk.13.1.76-82.

Nugroho, P. D. (2018). Pelaksanaan Lelang Terhadap Obyek Yang Dibebani Hak Tanggungan Dalam Rangka Mewujudkan Keadilan Para Pihak. RechtIdee, 13(2). https://doi.org/10.21107/ri.v13i2.4070.

Nurwulan, P. (2021). Implementasi Pelayanan Hak Tanggungan Elektronik Bagi Kreditor Dan Pejabat Pembuat Akta Tanah. Jurnal Hukum: IUS QUIA IUSTUM, 28(1). https://doi.org/10.20885/iustum.vol28.iss1.art9.

Pranoto, C. B. (2017). Pembangunan Negara, Hukum Pertanahan Indonesia,dan Kembalinya Tanah Kasultanan di Yogyakarta. Jurnal Politik, 3(1). https://doi.org/10.7454/jp.v3i1.49.

Pranoto, H. (2020). Sengketa Sertifikat Hak Milik Ganda Dalam Perspektif Teori Tujuan Hukum. DiH: Jurnal Ilmu Hukum, 16(1). https://doi.org/10.30996/dih.v16i1.2528.

Pratama, M. H. (2015). Implementasi Perlindungan Hukum Bagi Kreditor Dalam Pemberian Kredit Modal Kerja Tanpa Agunan (Studi di Danamon Simpan Pinjam Unit Turen). Arena Hukum, 7(1). https: //doi.org/10.21776/ub.arenahukum.2014.00701.3.

Prayuti, Y., Anggraeni, H. Y., \& Amalia, N. (2019). Kedudukan Sertifikat Hak Tanggungan Elektronik Sebagai Alat Bukti Dalam Pelaksanaan Eksekusi Langsung Berdasarkan Uu No. 4 Tahun 1996 Tentang Hak Tanggungan Atas Tanah Dan Benda Benda Yang Berkaitan Dengan Tanah. Jurnal Pemuliaan Hukum, 1(2). http://ojs.uninus.ac.id/index.php/Pemuliaan/article/view/1002.

Pribadi, A. (2017). Pengalihan Piutang Secara Cessie Atas Pembiayaan Dengan Jaminan Hak Tanggungan Pada Perbankan Syari'ah : Suatu Telaah Hukum Islam Dan Prinsip Perbankan Syari'ah. Jurnal Ius Constituendum, 2(2). https://doi.org/10.26623/jic.v2i2.657.

Ramadhani, M. H., Effendy, M., \& Qamariyanti, Y. (2019). Perolehan Tanah untuk Kepentingan Badan Hukum Swasta dalam Rangka Penanaman Modal. Lambung Mangkurat Law Journal, 10(4). https://doi.org/10.32801/lamlaj.v4i1.109.

Saragih, S., Kamello, T., \& Lubis, E. Z. (2018). Pemberian Kredit Modal Bergulir Untuk Koperasi Dan Usaha Kecil Dalam Rangka Pemberdayaan Ekonomi Rakyat Di Provinsi Sumatera Utara. Jurnal Mercatoria, 1(1). https://doi.org/10.31289/mercatoria.v1i1.726.

Sari, O. R. (2015). Pengaruh kepuasan dan motivasi kerja terhadap kinerja karyawan dengan Organizational Citizenship Behavior (OCB) sebagai variabel intervening. Management Analysis Journal, 4(1), 28-35. https://doi.org/10.15294/maj.v4i1.7221.

Setiawan, D., Gozali, D. S., \& Mispansyah, M. (2018). Kedudukan Hukum Akta Pernyataan dan Kuasa untuk Roya (Konsen Roya)dalam Proses Lelang. Lambung Mangkurat Law Journal, 3(2). https://doi.org/10.32801/lamlaj.v3i2.89.

Sinha, S. K., \& Verma, P. (2020). Impact of sales Promotion's benefits on perceived value: Does product category moderate the results? Journal of Retailing and Consumer Services, 52. https://doi.org/10.1016/j.jretconser.2019.101887.

Situmorang, H., Damanik, B., Sibagariang, S., \& Manurung, I. H. G. (2019). Aplikasi Sistem Pendukung Keputusan Analisis Kelayakan Pemberian Kredit Menggunakan Metode Topsis Pada Perusahaan Leasing Cs Finance. CESS (Journal of Computer Engineering, System and Science), 4(3). https://doi.org/10.24114/cess.v4i2.14057.

Surbakti, B. N., Yulfasni, Y., \& Razak, S. (2018). Pembuatan Surat Kuasa Membebankan Hak Tanggungan (SKMHT) Pada Pengalihan Hutang Kredit Di PT. BRI Agro Cabang Pekanbaru. Nagari Law Review, 2(1). https://doi.org/10.25077/nalrev.v.2.i.1.p.1-12.2018.

Susilaningsih, T. (2019). PTSL Wujud Pelaksanaan Kewajiban Pemerintah untuk Menjamin Kepastian dan Perlindungan Hukum Atas Kepemilikan Tanah. Cakrawala Hukum, 10(1). https://doi.org/10.26905/idjch.v10i1.3114.

Tadesse, G., \& Zewdie, T. (2019). Grants vs. credits for improving the livelihoods of ultra-poor: Evidence from Ethiopia. World Development 113. https://doi.org/10.1016/j.worlddev.2018.09.009.

Waryanta, W. (2016). Integrasi Penataan Pertanahan Dalam Kerangka "Penataan Wilayah Pesisir Dan Lahan Atas Terpadu." BHUMI: Jurnal Agraria Dan Pertanahan, 2(1). https: //doi.org/10.31292/jb.v2i1.28.

Widiarti, A. (2018). Perbuatan Melawan Hukum Dalam Perjanjian Jual-Beli Apartemen Secara Kredit 
Ditinjau Dari Pasal 1338 Ayat (3) Kitab Undang-Undang Hukum Perdata Dan Undang-Undang Nomor 8 Tahun 1999 Tentang Perlindungan Konsumen. Krtha Bhayangkara, 12(1). https://doi.org/10.31599/krtha.v12i1.34.

Wiguna, I. W. J. B. (2020). Tinjauan Yuridis Terkait Pendaftaran Hak Tanggungan Secara Elektronik. Jurnal Hukum Kenotariatan, 5. https://doi.org/10.24843/AC.2020.v05.i01.p07.

Yulianingsih, W., \& Noviana, D. S. (2012). Perlindungan Hukum Bagi Bank Sebagai Kreditur Pemegang Hak Tanggungan Berobyek Hak Guna Bangunan (HGB). Perspektif Hukum Journal, 12(2). https://doi.org/10.30649/phj.v12i2.40. 